\section{Biological Oxidation of Grayanotoxin-II to the 3-Dehydro Derivative by a Microorganism}

\author{
Ryozo IrIYE and Tetsugo HAYASHI \\ Department of Agricultural Chemistry, Faculty \\ of Agriculture, Shinshu University, Minami- \\ minowa-mura 8304, Kamiina-gun, \\ Nagano-ken, Japan
}

Received July 5, 1976

Grayanotoxin (G)-II (1), $\mathrm{C}_{20} \mathrm{H}_{32} \mathrm{O}_{5}, \operatorname{mp~} 196 \sim 8^{\circ} \mathrm{C}$, is one of the toxic diterpene alcohols obtained from Leucothoe grayana Max (Ericaceae). ${ }^{12}$ These alcohols are known for their novel carbon skeleton. We elucidated the biological oxidation of G-II (1) by a microorganism to give 3-dehydro $\mathrm{G}$-II (2), $\mathrm{C}_{20} \mathrm{H}_{30} \mathrm{O}_{5}$, $\operatorname{mp} 233^{\circ} \mathrm{C}$.

\section{MATERIALS AND METHODS}

G-II (1) was isolated from the dried leaves of Leucothoe grayana Max in the manner described by S. Miyajima and S. Takei. ${ }^{1 a}$ The microorganism ${ }^{2)}$ (Pseudomonas pseudomallei) used was selected through growth tests on agar slants $(2.0 \%$ agar and the basal medium, described in Table I, with $0.0025 \% \mathrm{G}-\mathrm{II}$ ). The biological oxidation was carried out as below. $\mathrm{G}-\mathrm{II}$ (1) was incubated with the microorganism at $30^{\circ} \mathrm{C}$ in the basal medium under aerobic conditions. The reaction period and the amounts of the substrate added are shown in Table II. Conditions are shown in the footnotes. Isolation of the products was carried out in the usual manner. After removing biomass by centri-
TAble I. Composition of the Medium

\begin{tabular}{lrll}
\hline $\mathrm{H}_{2} \mathrm{O}$ & $1000 \mathrm{~g}$ & $\mathrm{Na}_{2} \mathrm{MoO}_{4}$ & $0.0006 \mathrm{~g}$ \\
$\mathrm{MgSO}_{4} \cdot 7 \mathrm{H}_{2} \mathrm{O}$ & 0.2 & $\mathrm{MnSO}_{4}$ & 0.0006 \\
$\mathrm{CaCl}_{2} \cdot 2 \mathrm{H}_{2} \mathrm{O}$ & 0.1 & $\mathrm{Na}_{2} \mathrm{HPO}_{4} \cdot 12 \mathrm{H}_{2} \mathrm{O} 9.55$ \\
$\mathrm{FeSO}_{4} \cdot 7 \mathrm{H}_{2} \mathrm{O}$ & 0.1 & $\mathrm{KH}_{2} \mathrm{PO}_{4}$ & 0.9 \\
$\mathrm{NH}_{4} \mathrm{NO}_{8}$ & 1.0 & $(\mathrm{pH} 7.2 \sim 7.3)$ & \\
\hline
\end{tabular}

fugalization the culture broth was continuously extracted with ether and the extract was purified by successive crystalizations from ethyl acetate. When the extract contained the substrate, the product was isolated by preparative TLC (silica gel, $\mathrm{C}_{6} \mathrm{H}_{6}: \mathrm{Et}_{2} \mathrm{O}$ : $\mathrm{EtOH}=5: 2: 0.5,3$ developments). Substances were detected as white bands on spraying water and extracted from silica gel with the mixed solvent of ethyl acetate and ethanol $(3: 1)$. Yields of the product are shown in Table II.

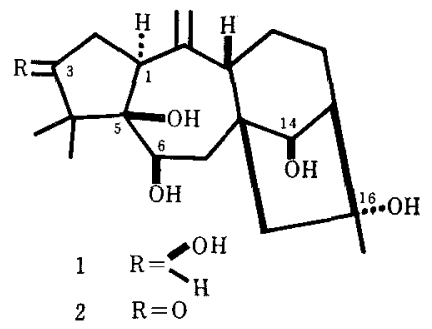

FIG. 1.

\section{RESULTS AND DISCUSSION}

On TLC analysis of the extracts, a clear spot of the main product (2) was detected at $R f 0.44$ ( 2 developments). A faint spot was also observed at $R f 0.53$ in process 1 , and in process 4 faint spots appeared at $R f$ $0.34,0.53,0.64,0.71,0.81$ and 0.93 from the residue of the mother liquid $(2.5 \%)$. As shown in Table II, the activity of the microorganism decreased in processes 2 and 3 . In process 3 , the product (2) was detected on

Table II. Culture Period and Yields of 3-Dehydro G-II

\begin{tabular}{|c|c|c|c|c|c|c|c|}
\hline \multirow[t]{2}{*}{ Process } & \multicolumn{2}{|c|}{$\begin{array}{l}\mathrm{G}-\mathrm{II} \\
\text { incubated }\end{array}$} & \multirow{2}{*}{$\frac{\text { Period }}{\text { days }}$} & \multicolumn{2}{|c|}{$\begin{array}{c}\text { Yields of } \\
\text { 3-dehydro G-II }\end{array}$} & \multicolumn{2}{|c|}{$\begin{array}{c}\text { G-II } \\
\text { recovered }\end{array}$} \\
\hline & $\mathrm{mg}$ & & & $\overline{\mathrm{mg}}$ & $(\%)$ & $\mathrm{mg}$ & $(\%)$ \\
\hline 1 & 5 & 1 & $2^{a}$ & 4.3 & (86) & 0 & $(0)$ \\
\hline 2 & 25 & 1 & $8^{a}$ & 8.0 & (32) & 16 & (64) \\
\hline 3 & 5 & 1 & $7^{b}$ & + & (0) & 4.5 & $(90)$ \\
\hline 4 & 20 & 1 & $30^{b}$ & 12.0 & (60) & 0 & $(0)$ \\
\hline
\end{tabular}

Microorganism: In process 1, the microorganism (100 150 mg, wet weight) used was grown on an agar slant similar to that used for cell selection. In processes 2 to 4 , cells separated from the culture broth in the preceding process were used.

Medium: $\quad 100 \mathrm{ml}$.

Addition of G-II: G-II was added by the feeding method.

$$
\text { a } 2.5 \sim 3.0 \mathrm{mg} / \text { day. } \quad \text { b } 2.5 \mathrm{mg} / 3 \sim 4 \text { days. }
$$




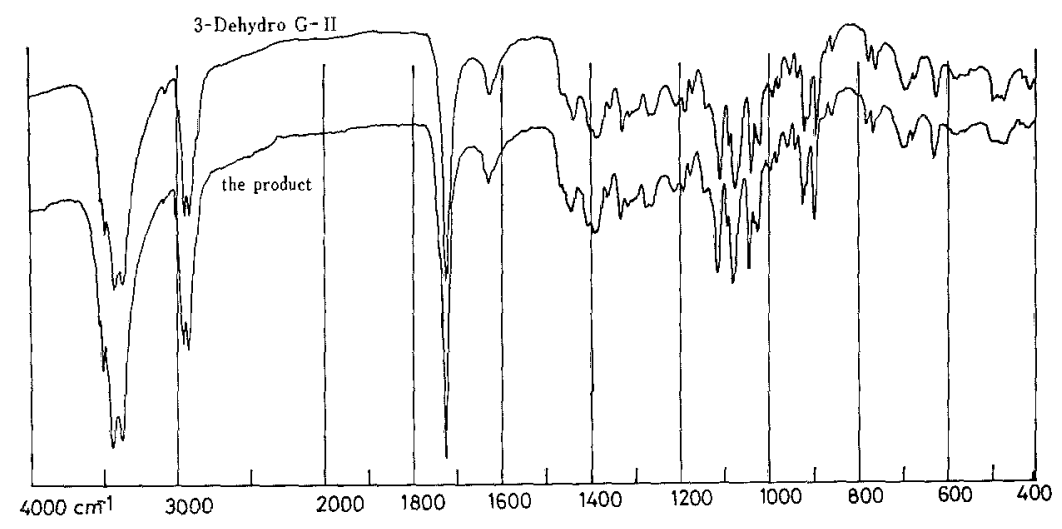

FIG. 2.

TLC analysis as a faint spot. In process 4 , the activity was recovered and the substrate (1) was oxidized by the microorganism to give 3 -dehydro G-II (2) (60\% yield).

The main product was determined to be 3-dehydro G-II (2) from its spectral data. The product (2), $[\alpha]_{D}=-105^{\circ}(c=0.23$, ethanol $)$, showed the parent peak at $m / e 350\left(\mathrm{C}_{20} \mathrm{H}_{30} \mathrm{O}_{8}\right)(6.8 \%)$ and several peaks at $m / e 349(10.5), 332\left(\mathrm{M}^{+}-\mathrm{H}_{2} \mathrm{O}\right)(18.5), 315(25.4)$, $314\left(\mathrm{M}^{+}-2 \mathrm{H}_{2} \mathrm{O}\right)(100), 296\left(\mathrm{M}^{+}-3 \mathrm{H}_{2} \mathrm{O}\right)(28.6), 286$ $(19.5), 285(24.4), 175(25.2), 149$ (26.1) and $119(42.8)$ on the MS spectrum. On IR spectrum $(\mathrm{KBr})$, the product (2) showed absorptions due to hydroxyls ( 3600 , $\left.3520,3450,3380 \mathrm{~cm}^{-1}\right)$, a carbonyl(1735) and a terminal methylene $(1646,889)$. The NMR spectrum (Pyr. $\left.-\mathrm{d}_{3}+\mathrm{D}_{2} \mathrm{O}\right)$ showed signals due to three tertiary methyls $(\delta: 1.14, \mathrm{~s}, 1.47, \mathrm{~s}, 1.52$, s), several methynes $(o: 4.46$, $\left.\mathrm{s}, \mathrm{C}_{14}-\mathrm{H} ; 4.71, \mathrm{t}, J=6, \mathrm{C}_{6}-\mathrm{H}\right)$ and a terminal methylene $(\delta: 5.09, \mathrm{~s}, 5.19, \mathrm{~s})$. The spectrum was very similar to that of G-II (1), but lacked the signal corresponding to the $\mathrm{C}_{3}$-methine proton of $\mathrm{G}-\mathrm{II}$ (1). Thus, the product was determined to be 3-dehydro G-II (2) and was identified with the authentic specimen ${ }^{3)}$ derived from
G-II (1) by its IR spectrum as shown in Fig. 2 .

The reactivity of the secondary hydroxyl groups of G-II (1) toward acetylation was found to be in the decreasing order of $\mathrm{C}_{9}-, \mathrm{C}_{6}-$ and $\mathrm{C}_{14}-$ hydroxyl group, but the reactivity toward hydrolysis showed the order of $\mathrm{C}_{8}-, \mathrm{C}_{3}-$ and $\mathrm{C}_{14}-$ hydroxyl group. ${ }^{3)}$ In this case, it was found that the microorganism oxidized the most reactive hydroxyl group of G-II (1) toward acetylation.

\section{REFERENCES}

1) a. S. Miyajima and S. Takei, Nippon Nôgeikagaku Kaishi, 12, 497 (1936). b. J. Iwasa, Z. Kumazawa and M. Nakajima, Agric. Biol. Chem, 25, 782, 793 and 798 (1961). c. Z. Kumazawa and R. Iriye, Tetrahedron Lett., 1970, 927; J. Iwasa and Y. Nakamura, ibid., 1969, 3973.

2) T. Hayashi, T. Kakimoto, H. Ueda and C. Tatsumi, Nippon Nógeikagaku Kaishi, 43, 583 (1969).

3) R. Iriye and T. Hayashi, Agric. Biol. Chem., 41, 1513 (1977). 